\title{
TORACOLOMBAR BURST FRACTURES AND SPINOPELVIC BALANCE
}

\author{
FRATURA TORACOLOMBAR DO TIPO EXPLOSÃO E EQUILÍBRIO ESPINOPÉLVICO \\ FRACTURA TORACOLUMBAR DEL TIPO EXPLOSIÓN Y EQUILIBRIO ESPINOPÉLVICO

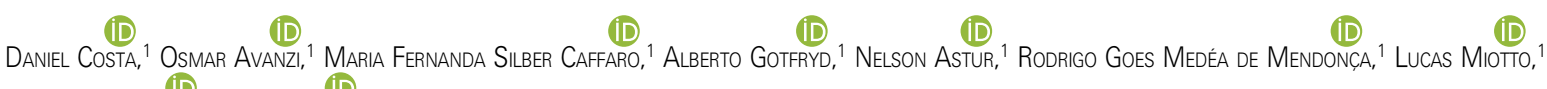 \\ Nathalia KawaKami, ${ }^{1}$ Robert MeVES ${ }^{1}$ \\ 1. Irmandade da Santa Casa de Misericórdia de São Paulo, São Paulo, SP, Brazil.
}

\begin{abstract}
Objective: To describe the spinopelvic parameters in patients with conservatively treated thoracolumbar burst fractures. Methods: Twenty-six patients with thoracolumbar burst fractures treated conservatively between 2008 and 2017 participated in the study. Inclusion criteria were acute burst-type fractures, located between T11 and L2, which compromised a single vertebral segment, did not present a neurological deficit, and had a minimum of 6 months of follow-up, excluding injuries that presented distraction or rotation, pathological fractures, and surgically treated cases. The sagittal and spinopelvic alignment parameters, including vertical sagittal axis, sacral slope, pelvic tilt, pelvic incidence, lumbar lordosis, and regional kyphosis, were analyzed. Results: The values obtained for the sample showed that there was an increase in regional kyphosis and that the mean sagittal parameters and lumbar lordosis were within the values considered normal in the literature. Conclusion: Patients with thoracolumbar burst fractures treated conservatively had no alterations in the spinopelvic parameters. Level of Evidence II; Retrospective study.
\end{abstract}

Keywords: Thoracic Vertebrae; Postural Balance; Lumbar Vertebrae; Fractures, Bone.

\section{RESUMO}

Objetivo: Descrever os parâmetros espinopélvicos de pacientes com fratura toracolombar tipo explosão tratados de modo conservador. Métodos: Participaram do estudo 26 pacientes com fratura toracolombar do tipo explosão tratados conservadoramente entre 2008 e 2017 . Os critérios de inclusão consistiam em: fraturas tipo explosão agudas, localizadas entre $T 11$ e $L 2$, as quais comprometiam um único segmento vertebral, não apresentavam déficit neurológico e tinham no mínimo seis meses de acompanhamento, excluídas as lesões que apresentavam componente de distração, rotação, fraturas patológicas e casos tratados cirurgicamente. Foram analisados os parâmetros do alinhamento sagital e espinopélvico, incluindo o eixo sagital vertical, a inclinação sacral, a versão pélvica, a incidência pélvica, lordose lombar e cifose regional. Resultados: Os valores obtidos na amostra demonstraram que houve aumento da cifose regional e que a média total dos parâmetros sagitais e de lordose lombar estão dentro dos valores considerados normais na literatura. Conclusões: Os pacientes com fraturas toracolombares tipo explosão, tratados de modo consenvador, não apresentaram alterações nos parâmetros espinopélvicos. Nível de evidência II; Estudo retrospectivo.

Descritores: Vértebras Torácicas; Equilíbrio Postural; Vértebras Lombares; Fraturas Ósseas.

\section{RESUMEN}

Objetivo: Describir los parámetros espinopélvicos de pacientes con fractura toracolumbar tipo explosión tratados de modo conservador. Métodos: Participaron en el estudio 26 pacientes con fractura toracolumbar del tipo explosión, tratados conservadoramente entre 2008 y 2017. Los criterios de inclusión consistían en: fracturas tipo explosión agudas, localizadas entre T11 y L2, las cuales comprometían un único segmento vertebral, no presentaban déficit neurológico y tenían como mínimo 6 meses de acompañamiento,, excluidas las lesiones que presentaban componente de distracción, rotación, fracturas patológicas y casos tratados quirúrgicamente. Fueron analizados los parámetros de la alineación sagital y espinopélvica, incluyendo el eje sagital vertical, la inclinación sacral, la versión pélvica, la incidencia pélvica, lordosis lumbar y cifosis regional. Resultados: Los valores obtenidos en la muestra demostraron que hubo aumento de la cifosis regional y que el promedio total de los parámetros sagitales y de lordosis lumbar están dentro de los valores considerados como normales en la literatura. Conclusiones: Los pacientes con fracturas toracolumbares tipo explosión, tratados de modo conservador, no presentaron alteraciones en los parámetros espinopélvicos. Nivel de evidencia II; Estudio retrospectivo.

Descriptores: Vértebras Torácicas; Balance Postural; Vértebras Lumbares; Fracturas Óseas.

\section{INTRODUCTION}

Thoracolumbar burst fractures result from axial compression with breakage of the anterior and middle columns of the vertebral body $^{1}$ and account for $15 \%$ of all spinal fractures. ${ }^{2}$

One of the most common complications of thoracolumbar fractures is the increase in localized kyphosis. ${ }^{3}$ It is known that sagittal misalignment of the spine is related to pain and worsening of the quality of life. ${ }^{4}$

There is controversy in the current literature about the impact of an increase in thoracolumbar kyphosis on normal spinopelvic balance. Thus, the objectives of this study were to describe and analyze whether there are changes in the spinopelvic parameters of patients with conservatively treated thoracolumbar burst fractures. 


\section{METHODS}

After approval by the FCMSCSP Institutional Review Board (CAAE: 67065617.4.0000.5479), a descriptive, cross-sectional study of 26 patients with thoracolumbar burst fractures conservatively treated between 2008 and 2017 was conducted. All patients included in this study agreed with the terms of the Informed Consent Form (ICF).

In all the cases the treatment was performed using a TLSO or antigravity cast from four to six months. The patients were encouraged to walk as early as possible, to the extent that the pain resulting from the fracture decreased.

Burst fractures located between $\mathrm{T} 11$ and $\mathrm{L} 2$, involving a single vertebral segment, without neurological deficit, and with a minimum follow-up of six months were included in the study. Injuries with distraction, rotation, pathological fractures, and surgically treated cases were excluded.

The study participants were selected at a treatment referral center for thoracolumbar burst fractures and, because this was a cross-sectional study, we had a loss in the number of patients, ending up with a final sample of 26 cases that met the inclusion criteria

Radiographic analysis was conducted by means of panoramic anteroposterior and lateral incidence spinal images, in which the study of spinopelvic parameters, Cobb angle, and regional kyphosis was performed (Figures 1 and 2). No significant differences were observed in the percentages of height loss of the fractured vertebrae.

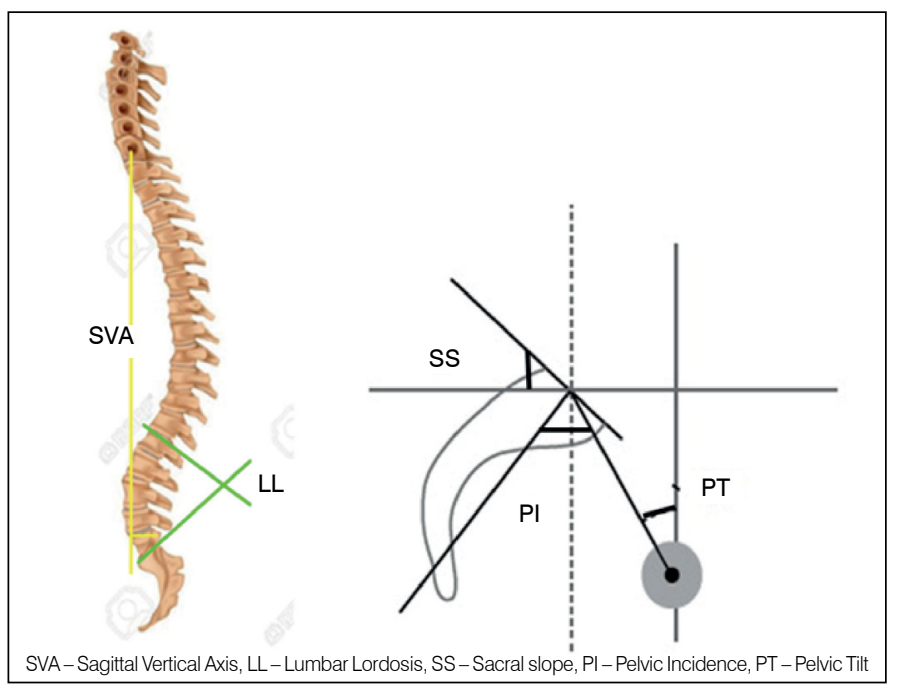

Figure 1. Illustration of the spinopelvic parameters.
The radiographic parameters evaluated were

a. Pelvic incidence: the angle formed between the line perpendicular to the midpoint of the sacral plateau of S1 and the line connecting this point to the medial axis of the femoral heads. ${ }^{5}$

b. Sacral slope: the angle formed between the superior plate of S1 and the horizontal plane line. ${ }^{5}$

c. Pelvic tilt: the angle formed between the line connecting the midpoint of the S1 plateau to the axis of the femoral heads and the vertical line. ${ }^{5}$

d. Sagittal plumb line: measured by the distance between the line originating in the center of the body of $\mathrm{C} 7$ and the posterosuperior corner of the sacrum. ${ }^{6}$

e. Cobb angle of lumbar lordosis: the angle drawn from lines perpendicular to the inferior plateau of $\mathrm{T} 12$ and the superior plateau of $\mathrm{S} 1 .{ }^{7}$

The categorical data were described as absolute numbers and percentages. All the continuous data were submitted to distribution analysis using the Shapiro-Wilk test. The radiographic variables were compared between the sexes and subsequently with the literature data using the Student's t test for independent samples.

\section{RESULTS}

Twenty-six patients met the inclusion criteria and were selected for the study. Of these, 20 were male and 5 were female. The mean patient age was 52.5 years, ranging from 27 to 76 years, with a mean age of 53.1 years for the men and 49.5 years for the women.

The fractures occurred in the thoracolumbar transition, with 13 (46\%) in L1, 8 (31\%) in T12, 3 (11.5\%) in L2, and 3 (11.5\%) in T11. All the fractures were classified by the AO system, according to which $57 \%$ were type $A 3$ and $43 \%$ were type $A 4$.

Table 1 shows the results with the mean and standard deviation values of the spinopelvic parameters, lumbar lordosis, and regional kyphosis of the sample.

Mean pelvic incidence was 62.1 degrees, ranging from 31 to 107 degrees; mean sacral slope was 34.1 degrees, with a minimum of 12 and a maximum of 59 degrees; and mean pelvic tilt was 27.8 degrees, ranging from 1 to 76 degrees. Regional kyphosis was 21.11 degrees, with a minimum of 6 and a maximum of 39 degrees. Lumbar lordosis had a mean value of 55.5 degrees with a minimum of 16 and a maximum of 108 degrees. The sagittal vertical axis had a mean value of $0.4 \mathrm{~cm}$, ranging from -0.1 to $10 \mathrm{~cm}$.

Table 2 shows pelvic incidence, sacral slope, pelvic tilt, and sagittal vertical axis study results compared to those of healthy Brazilian subjects. ${ }^{8}$

Statistically significant differences were observed between pelvic

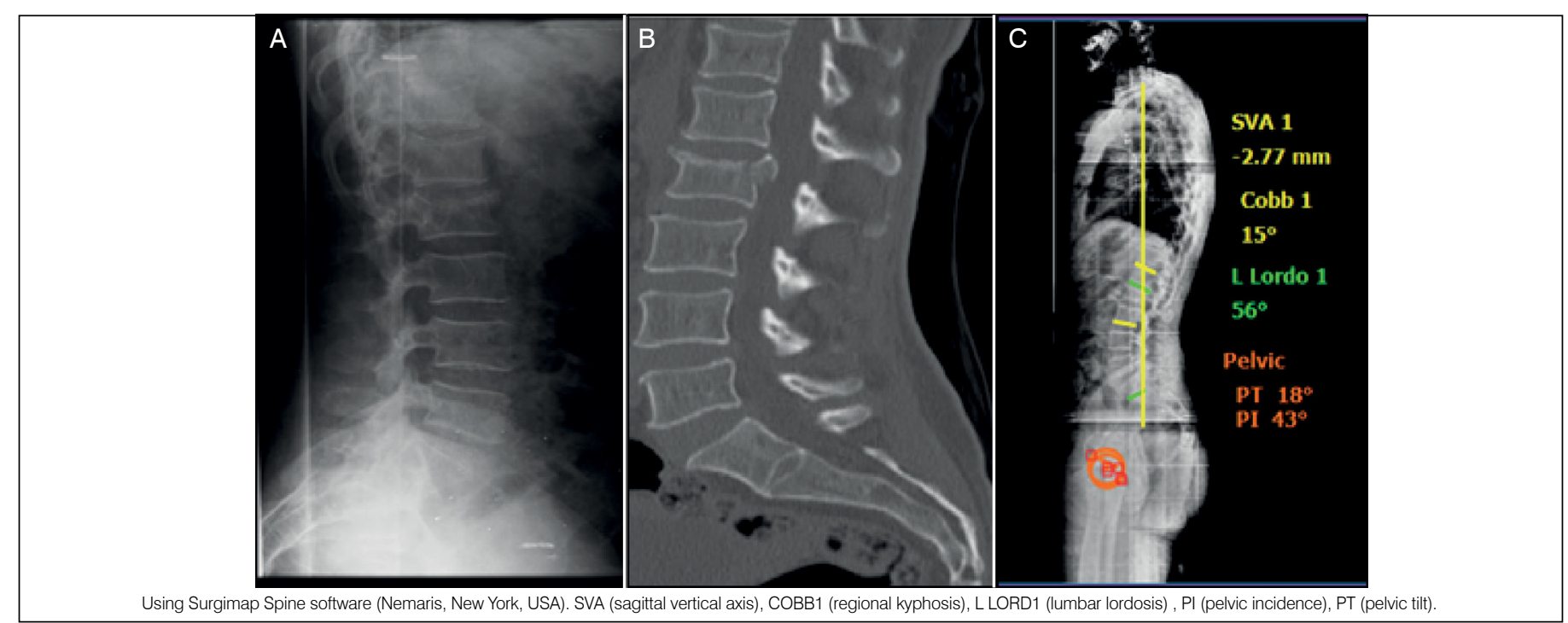

Figure 2. Female patient, 72 years, with $L 1$ fracture. (a) initial radiograph, (b) radiograph after 6 months of follow-up with radiographic parameter measurements (using Surgimap Spine software (Nemaris, New York, USA)). 
incidence, pelvic tilt and sagittal vertical axis values, which were higher in patients who had fractures $(p=0.0049, p=0.0003$ and $p=0.0001$, respectively). No statistically significant difference was observed between the sacral slope values of the two groups $(p=0.101)$.

In Table 3, the comparisons of the pelvic incidence, sacral slope, and pelvic tilt study results with values of other ethnic populations are shown.

The mean pelvic incidence in the fracture group was higher than and statistically different from the Korean group (p2=0.0026). Sacral slope in the fracture group was also statistically higher than that of the European group. We observed statistically significant differences among the three groups, with the pelvic tilt being higher than those of the Korean and European groups ( $1=0.0004$ and $p 2=0.0001$ ).

When compared to literature reference values, pelvic incidence, sacral slope, lumbar lordosis, and regional kyphosis were all within the normal range of values. Only mean pelvic tilt was higher, as shown in Table 4.

Table 1. Parameters measured in the patients with thoracolumbar burst fracture

\begin{tabular}{c|c|c|c|c|c|c}
\hline & \multicolumn{2}{|c|}{$\begin{array}{c}\text { Total } \\
(\mathbf{n = 2 6 )}\end{array}$} & \multicolumn{2}{c|}{$\begin{array}{c}\text { Male } \\
(\mathbf{n = 2 1 )}\end{array}$} & \multicolumn{2}{c}{$\begin{array}{c}\text { Female } \\
(\mathbf{n = 5}\end{array}$} \\
\hline & Mean & Sd & Mean & Sd & Mean & Sd \\
\hline Pelvic incidence $\left(^{\circ}\right)$ & 62.1 & 21.4 & 63.9 & 20.9 & 54.2 & 24.3 \\
\hline Sacral slope $\left(^{\circ}\right)$ & 34.1 & 10.2 & 35.8 & 9.6 & 27 & 10.7 \\
\hline Pelvis tilt $\left(^{\circ}\right)$ & 27.8 & 17.8 & 27.9 & 18.1 & 27.2 & 18.2 \\
\hline SVA (cm) & 0.4 & 0.3 & 0.4 & 0.3 & 0.3 & 0.2 \\
\hline Lumbar lordosis $\left(^{\circ}\right)$ & 55.5 & 17.4 & 55.4 & 19 & 55.6 & 8.8 \\
\hline Regional kyphosis $\left(^{\circ}\right)$ & 21.11 & 9.83 & 21 & 10 & 21.2 & 10 \\
\hline
\end{tabular}

SD - Standard Deviation; SVA - Sagittal Vertical Axis; $\mathrm{cm}$ - centimeters; $\left(^{\circ}\right)$ - degrees. Source: SAME-SCSP.

Table 2. Comparison of the spinopelvic parameters of patients with thoracolumbar burst fractures and asymptomatic Brazilian subjects. ${ }^{8}$

\begin{tabular}{c|c|c|c|c|c}
\hline & \multicolumn{2}{|c|}{$\begin{array}{c}\text { Fracture group } \\
(\mathbf{n}=\mathbf{2 6})\end{array}$} & \multicolumn{2}{c|}{$\begin{array}{c}\text { Asymptomatic } \\
\text { group (n= 50) }\end{array}$} & P-value \\
\hline & Mean & SD & Mean & SD & \\
\hline Pelvic incidence $\left(^{\circ}\right)$ & 62.1 & 21.4 & 48.7 & 9.6 & 0.0049 \\
\hline Sacral slope $\left(^{\circ}\right)$ & 34.1 & 10.2 & 38 & 8.4 & 0.101 \\
\hline Pelvic tilt $\left(^{\circ}\right)$ & 27.8 & 17.8 & 12.5 & 6.2 & 0.0003 \\
\hline SVA $(\mathrm{cm})$ & 0.4 & 0.3 & -1.735 & 3.7 & 0.0001 \\
\hline
\end{tabular}

SD - Standard Deviation, SVA - Sagittal Vertical Axis, cm - centimeters, $\left(^{\circ}\right)$ - degrees.

Table 3. Comparison between the spinopelvic parameters of the patients with thoracolumbar burst fractures and European and Korean subjects. ${ }^{8}$

\begin{tabular}{|c|c|c|c|c|c|c|c|c|}
\hline & \multicolumn{2}{|c|}{$\begin{array}{c}\text { Fracture } \\
\text { group } \\
(n=26)\end{array}$} & \multicolumn{2}{|c|}{$\begin{array}{c}\text { European } \\
\text { group } \\
(\mathbf{N}=\mathbf{3 0 0})\end{array}$} & \multicolumn{2}{|c|}{$\begin{array}{l}\text { Korean } \\
\text { group } \\
(n=86)\end{array}$} & \multirow[t]{2}{*}{$\begin{array}{c}\mathrm{P} 1- \\
\text { value }\end{array}$} & \multirow[t]{2}{*}{$\begin{array}{c}\text { P2- } \\
\text { value }\end{array}$} \\
\hline & MEAN & SD & MEAN & SD & MEAN & SD & & \\
\hline Pelvic incidence $\left({ }^{\circ}\right)$ & 62.1 & 21.4 & 54.7 & 10.6 & 47.8 & 9.5 & 0.0929 & 0.0026 \\
\hline Sacral slope $\left(^{\circ}\right)$ & 34.1 & 10.2 & 41.2 & 8.5 & 36.3 & 8.6 & 0.0019 & 0.325 \\
\hline Pelvic tilt( $\left(^{\circ}\right)$ & 27.8 & 17.8 & 13.2 & 6 & 11.5 & 5.4 & 0.0004 & 0.0001 \\
\hline
\end{tabular}

Korean groups, SD - Standard Deviation, $\left({ }^{\circ}\right)$ - degrees.

Table 4. Comparison between sample values and normal values reported in the literature..$^{9-13}$

\begin{tabular}{|c|c|c|c|}
\hline & \multicolumn{2}{|c|}{ Fracture group $(n=26)$} & \multirow[t]{2}{*}{ Normal values } \\
\hline & Mean & SD & \\
\hline Pelvic incidence $\left({ }^{\circ}\right)$ & 62.1 & 21.4 & $40-65$ \\
\hline Sacral slope $\left(^{\circ}\right)$ & 34.1 & 10.2 & $30-50$ \\
\hline Pelvic tilt( $\left.{ }^{\circ}\right)$ & 27.8 & 17.8 & $10-25$ \\
\hline SVA $(\mathrm{cm})$ & 0.4 & 0.3 & $0.5 \mathrm{~cm}( \pm 2.5 \mathrm{~cm})$ \\
\hline Lumbar lordosis $\left({ }^{\circ}\right)$ & 55.5 & 17.4 & $40-60$ \\
\hline
\end{tabular}

\section{DISCUSSION}

Burst fractures are frequently observed today, especially in polytrauma patients. ${ }^{14}$ There is no consensus around the treatment of these injuries, especially in patients with neurological deficit. ${ }^{15-17}$

The objective of this study, conducted at our institution, was to show and describe changes in the spinopelvic parameters of patients with thoracolumbar burst fractures without neurological deficit who were treated conservatively. The authors hypothesized that patients who underwent conservative treatment for thoracolumbar fractures might present changes to normal sagittal balance.

For this analysis, we compared the mean values and standard deviations obtained in this study with values published in the literature, with a sample of asymptomatic Brazilian subjects, and with other ethnic populations. ${ }^{8}$

It is known that there is a risk of late sagittal collapse with worsening of thoracolumbar kyphosis, especially in those submitted to non-surgical treatment. ${ }^{18}$ Risk factors include loss of height greater than $50 \%$, translation greater than $2.5 \mathrm{~mm}$, spinal canal involvement greater than $50 \%$, or signs of posterior ligament rupture. ${ }^{19}$

The results presented in the sample showed an increase in mean regional kyphosis, however, these changes in localized kyphosis did not change the patients' spinopelvic parameters. The most likely explanation for this stability is the compensatory mechanisms, which were sufficient to preserve the balance of the trunk in these patients.

Several authors highlight the relevance of changes in the sagittal plane and of the relationship between the spine and changes in pelvic orientation. These concepts originated from the French studies pioneered by Jean Dubosset and Legaye \& Duval-Beaupere. ${ }^{16}$

The symptoms caused by imbalance in the sagittal plane manifest as pain in the low back, gluteal muscles, and lower limbs, gait difficulties, fatigue, and spasms of the spinal erector muscles associated with hip extension and knee flexion. ${ }^{20}$

The mean pelvic incidence, pelvic tilt, and sagittal vertical axis values in the patients who suffered thoracolumbar fractures were elevated as compared to the values in the asymptomatic Brazilian population sample. This difference may have occurred because of the physical characteristics and race of the patients participating in the sample. No difference in sacral slope was observed.

According to Legaye and Duval-Beaupere et al., ${ }^{21}$ there is significant interdependence between pelvic and spinal parameters. Pelvic incidence determines pelvic orientation and the scope of lordosis. A low pelvic value implies low pelvic parameter values and flattened lordosis. A high pelvic incidence value implies an inclined pelvis and pronounced lordosis. Changes not found in our patients, among whom the mean lumbar lordosis and sacral slope were within the normal ranges of values reported in the literature. ${ }^{20,21}$

When we compared our spinopelvic parameter values to those of other ethnic populations, there were divergences between them. Mean pelvic incidence in the fracture group was statistically higher than that of the Korean group. Mean sacral slope was higher in the fracture group than in the European group. Comparisons of mean pelvic tilt revealed differences among the three groups, the fracture group values being higher than those of both the Korean and European groups.

Thoracolumbar burst fractures treated conservatively presented increases in the spinopelvic parameters when compared to other groups of asymptomatic populations. The increase was due to the compensatory mechanisms of the pelvis. A complementary study of the quality of life of these patients would provide a more complete analysis of the relationship between thoracolumbar burst fractures and spinopelvic sagittal balance.

\section{CONCLUSION}

Patients with conservatively treated thoracolumbar burst fractures had an increase in thoracolumbar kyphosis, but with no changes to spinopelvic parameters or lumbar lordosis.

All authors declare no potential conflict of interest related to this article. 
CONTRIBUTION OF THE AUTHORS: Each author made significant individual contributions to the manuscript. DC, OA, MFSC, AG, NAN, RGMM, and LM participated in the discussion of the results and contributed to the review and approval of the final version of the work. DC, LM, NK, and RM actively participated in the data collection for this study.

\section{REFERENCES}

1. Holdsworth F. Fractures, dislocations, and fracture-dislocations of the spine. J Bone Joint Surg Am. 1963;45(1):6-20

2. Fakurnejad S, Scheer JK, Patwardhan AG, Havey RM, Voronov LI, Smith ZA. Biomechanics of thoracolumbar burst fractures: methods of induction and treatments. J Clin Neurosci. 2014:21(12):2059-64.

3. Avanzi O, Landim E, Meves R, Caffaro MFS, Umeta RS, Miguel Neto C. Conservative treatment of thoracolumbar burst fractures: radiographic analysis of post-traumatic kyphosis. Coluna/Columna. 2009:8(2):148-52.

4. Glassman SD, Berven S, Bridwell K, Horton W, Dimar JR. Correlation of radiographic parameters and clinical symptoms in adult scoliosis. Spine (Phila Pa 1976). 2005;30(6):682-8.

5. Berthonnaud E, Dimnet J, Roussouly P, Labelle H. Analysis of the sagittal balance of the spine and pelvis using shape and orientation parameters. J Spinal Disord Tech. 2005;18(1):40-7.

6. Tebet MA. Current concepts on the sagittal balance and classification of spondylolysis and spondylolisthesis. Rev Bras Ortop. 2014:49(1):3-12.

7. Damasceno LHF, Catarin SRG, Campos AD, Defino HLA. Lumbar lordosis: a study of angle values and of vertebral bodies and intervertebral discs role. Acta Ortop Bras. 2006;14(4):193-8

8. Pratali RDR, Luz CDO, Barsotti CEG, Dos Santos FPE, De Oliveira CEAS. Analysis of sagittal balance and spinopelvic parameters in a brazilian population sample. Coluna/Columna. 2014;13(2):108-11.

9. Roussouly P, Gollogly S, Berthonnaud E, Dimnet J. Classification of the normal variation in the sagittal alignment of the human lumbar spine and pelvis in the standing position. Spine (Phila Pa 1976). 2005;30(3):346-53.

10. Vialle R, Levassor N, Rillardon L, Templier A, Skalli W, Guigui P. Radiographic analysis of the sagittal alignment and balance of the spine in asymptomatic subjects. J Bone Joint Surg Am. 2005;87(2):260-7.
11. Marks MC, Stanford CF, Mahar AT, Newton PO. Standing lateral radiographic positioning does not represent customary standing balance. Spine (Phila Pa 1976). 2003:28(11):1176-82.

12. Barrey C, Jund Jm, Noseda O, Roussouly P. Sagittal balance of the pelvis-spine complex and lumbar degenerative diseases. A comparative study about 85 cases. Eur Spine J. 2007:16(9):1459-67.

13. Kapandji A. Fisiologia articular: tronco e coluna vertebral. São Paulo: Editora Panamericana. Rio de Janeiro: Guanabara Koogan; 2000

14. Avanzi $O$, Chih $L$, Meves R. Avaliação do tratamento cirúrgico tardio na fratura toracolombar tipo explosão. Coluna/Columna. 2002;1 (2):88-93

15. Wood K, Buttermann G, Mehbod A, Garvey T, Jhanjee R, Sechriest V. Operative compared with nonoperative treatment of a thoracolumbar burst fracture without neurological deficit: a prospective, randomized study. J Bone Joint Surg Am. 2003;85(5):773-81.

16. Chow GH, Nelson BJ, Gebhard JS, Brugman JL, Brown CW, Donaldson DH. Functional outcome of thoracolumbar burst fractures managed with hyperextension casting or bracing and early mobilization. Spine (Phila Pa 1976). 1996;21(18):2170-5.

17. Defino HL, Fuentes ARR, Remondi PH, Ballim EC. Tratamento conservador das fraturas da coluna toracolombar. Rev Bras Ortop. 2000;35(8):301-8.

18. Denis $F$. The three column spine and its significance in the classification of acute thoracolumbar spinal injuries. Spine (Phila Pa 1976). 1983;8(8):817-31.

19. Green DP. Rockwood and Green's fractures in adults. Philadelphia: Lippincott Williams \& Wilkins; 2010.

20. Lagrone M, Bradford D, Moe J, Lonstein J, Winter R, Ogilvie J. Treatment of symptomatic flatback after spinal fusion. J Bone Joint Surg Am. 1988;70(4):569-80.

21. Legaye J, Duval-Beaupere G, Hecquet J, Marty C. Pelvic incidence: a fundamental pelvic parameter for three-dimensional regulation of spinal sagittal curves. Eur Spine J. 1998;7(2):99-103. 